personally, and as surely vindicate himself. Those who have followed him in his practice, and adopted the precautions with which he hedges round the use of the cautery or the stronger escharotics, know that there is slight probability of mischief or danger. My own settled conviction, derived from practical experience, is, that those agents are not only safe, but necessary, and that by their means we successfully cope with erodent ulcer of the cervix, cauliflower excrescence, indurated ulceration, and other forms of disease, that without them are altogether intractable. Notwithstanding the "many bitter things" which have been said, the advocates of potassa fusa rise superior to Basil Valentine, so humorously spoken of in your last number; for while his brother monks succumbed to his experiment, our more interesting patients, previously bowed down with the pallor and dejection of uterine disease, are restored to health and comeliness. All the world would, I am sure, regret to see Dr. Tyler Smith descend from his high position to follow in the steps of Gui Patin

The late controversy has shown that, in truth, the battle of uterine pathology, \&c., has but begun. The question happily is thoroughly practical as well as scientific, and is easy of settlement by practical men. The "points" are well defined. On one side the broad principle is laid down, that in chronic intractable disease of the uterus the therapeutics are principally surgical, and that all surgical agents are not only admissible, but in turn requisite. On the other hand, Dr. Tyler Smith, accepting the pathological products of "inflammation," but ignoring the antecedent condition, affirms that the stronger escharotics are langerous, and therefore inalmissible, and that their use even is "mutilation." We must again ask for facts. Dr. Shute, of Torquay, has already ably responded, and has added one more link to a chain, which would encircle the island, could we but gather and connect the series. But can we not "collect evidence on the spot"? This would be of inestimable value. If I am not mistaken, Dr. Bennet was followed at the Western General Dispensary by Dr. Robert Barnes. Many cases would probably remain under treatment; some which had been previonsly treated might return. He would probably enter upon the very field worked by the disputants with no predetermined opinions on uterine pathology. So far as I know he has never published on the subject. In the present aspect of the question, his testimony would carry great weight. The question is no longer personal, but scientific; deeply interesting, no donbt, it is to the profession. It is vitally important to the female community-indeed I may say to the whole community. I hope therefore it will not be deemed impertinent to call thus publicly on Dr. Robert Barnes to make known his opinions on uterine disease and its treatment. This appeal I make to him most earnestly, and to it Dr. Bennet, I think, ought not, and Dr. Tyler Smith cannot, object.

$$
\text { I am, Sir, yours truly, }
$$

Horncastle, May, 1856.

B. J. Boulton, M.D.

\section{POISONING BY STRYCHNINE.}

To the Editor of THE LANCET.

SIR,-The article in your last number, upon the "Detection of Strychnine," by Mr. F. C. Calvert, of Manchester, does not appear to me to bear or throw any light upon the present question of strychnine poisoning.

No doubt if strychnine be administered in a larger quantity than is necessary to produce death, the overplus will remain in a comparatively easily detectible state; but the real question at present raised by late occurrences, and the one required to be determined is this : How long a time will strychnine, administered in that precise quantity which will cause death, remain unabsorbed by the general eirculation, so as to be detected with certainty? Again, is it possible that strychnine may kill and leave no trace of its presence? I ask these questions in the hope that some one of our acknowledged chemical and physiological anthorities may be induced to answer them. I remain, Sir, yours, \&c.,

Torrington-square, May, 1856 ,

G. DUPLEX.

\section{GRIEVANCES OF POOR-LAW SURGEONS.}

A MEETING of the medical profession of the northern division of the county of Wilts was held at Chippenham on Wednesday, April 30th, in support of Mr. Griffin's movement; presentMr. Jennings, of Malmesbury, (in the chair); Mr. F. Spencer and Dr. W. H. Colborne, Chippenham; Mr. Montgomery and Mr. Thomas B. Anstie, Devizes; Mr. T. H. King and Mr. 552
Cartwright, Colne; Mr. Kendrick and Mr. J. R. King, Melk. sham; Mr. Knaggs, Swindon; Mr. H. Crisp, Laeock; Mr. Fitzgerald, Avebury; Mr. Thos. Taylor, Cricklade; Dr. W. B. Smith, Corsham; Mr. Fdwin Smith, Sherston Magna; and Mr. C. Smith, Highworth.

After a few introductory remarks from the Chairman,

Mr. ANSTIE stated that the meeting had been convened by circulars issued by himself, at the request of Mr. Griffin, and with the approval of several of the medical practitioners of this nejghbourhood. He also stated that he had received thirty answers expressive of cordial acquiescence in the object of the meeting, but regretting the inability of the writers to be present. Mr. Anstie expressed his conviction that the movement now making throughout the kingdom, if but rightly stpported by all classes in the profession, would issue in some important result beneficial to all parties interested in it. He deprecated exceedingly its being regarded as a contest with local boards of guardians, but considered that it had for its aim the raising of the general status of the profession. He then moved the fol. lowing resolution:-

lst. - That this meeting regards the movement set on foot by Mr. Griffin as the natural and necessary result of the in. creased demand made upon the medical practitioner for educa. tion and its representative-skilled labour; and while therefore it offers Mr. Griffin its cordial thanks for his exertions in originating the movement, it also wonld recognise the claim which rests on the whole profession for its support.

Mr. Thomas King seconded the resolution; and Mr. Sмrтth, of Highworth, in supporting it, read a paper, in which, while he approved of the movement, he was anxions that the Poorlaw Board should be memorialized previous to any application being made to the House of Commons.

Dr. W. Colbonne, amongst other remarks tending to show the insufficiency of the remuneration made to the profession, stated that in one district, to his knowledge, while the num. ber of cases was increased within a few years sixfold, the salary remained the same. He then moved the following resolution :-

2nd. - That this meeting is of opinion that the present rate of payment of the medical officers of unions is quite inadequate to the labour and skill required at their hands. It considers that a general increase of salary is demanded, and that that increase shonld be apportioned to the number of cases requiring attendance, with a due regard to the number and length of journey.

Mr. KNAGGS, in seconding the foregoing resolution, made some reference to a plan for remunerating medical officers which he had lately published; but stated that, as the details would be more suited to the consideration of the approaching meeting in London, he should not detain the present meeting by a statement of it.

Mr. Montgomery proposed, and Mr. E. Smith seconded-

3rd. - That this meeting regards with satisfaction the proposed meeting of the profession in London, as suggested by Mr. Griffin, and will be happy to appoint such gentlemen to represent this meeting on that occasion as would volunteer so to do.

Three gentlemen present then offered their gratuitous services, if not prevented by urgent business.

Mr. CaRTwrighr proposed, and Mr. Spencer seconded-

4th. - That a subscription be entered into, for the furtherance of this object, of $5 s$. per quarter, to be continued as long as considered necessary, and which, after deducting the expenses attending this or similar meetings, should be handed over to Mr. Griffin.

Dr. M. B. SmITh proposed, and Mr. CRISP seconded-

5th. - That Mr. T. B. ANsTre be requested to act as secretary and treasurer.

The foregoing resolutions were carried unanimously, as also that the report of this meeting be forwarded to The LANCET, the Association Journal, and the Medical Times; and votes of thanks to the Chairman and Mr. Thomas B. Anstie for their services.

At a meeting of the Medical Officers of the Boston Union, held on the 30 th ult., the following resolutions were unanimously agreed to:-

lst. - That this meeting considers the movement made by Mr. Griffin, to improve the position and remuneration of the Union Surgeons, justly called for, and deserving their most energetic support; and that the thanks of this raeeting be given to Mr. Griffin.

2nd.-That the salaries of the Medical Offoers, compared with their arduous duties and the expenses of performing them, are "out of all reasonable match;" the cost of horsekeeping in the country districts, and of the medicines and appliances 